\title{
Rural Poverty Reduction Strategy for South Asia
}

\author{
Ganesh Thapa \\ International Fund for Agricultural Development \\ Rome
}

Paper Presented at an International Conference on Ten Years of Australian South Asia

Research Centre organized at the Australian National University, Canberra from 27-28

April 2004 


\title{
Rural Poverty Reduction Strategy for South Asia ${ }^{1}$
}

\author{
Ganesh Thapa ${ }^{2}$
}

\begin{abstract}
Roughly 40 percent of the world's poor live in South Asia, where poverty is basically a rural problem. Therefore, a significant gain in rural poverty reduction in this sub-region will be crucial to reach the international poverty reduction target. Based on the analysis and experience of the International Fund for Agricultural Development (IFAD), this paper argues that to be successful, poverty reduction policies in South Asia must focus on the less-favoured rural areas and on most disadvantaged sections of the rural poor (mainly women, the landless and indigenous peoples). In order to overcome disadvantages arising from remoteness, lack of social services, insecure and unproductive jobs, and discrimination as women or ethnic minorities, the rural poor need legally secure access to productive assets (mainly land, forests and water); sustainable or regenerating agricultural technology; access to markets; opportunities to participate in decentralized resource management; and access to financial services.
\end{abstract}

\section{Introduction}

Although the share of South Asia in the world's total poor declined by roughly 10 percentage points between 1990 and 2000, this region still accounts for about 40 percent of the total poor (Table 1). Using the headcount ratio, about one third of the population in South Asia was under the poverty line in 2000. The success of poverty reduction in South Asia will be crucial in the achievement of the Millennium Development Goal of halving poverty by the year 2015 .

Within Asia and the Pacific Region, the progress in poverty reduction has varied widely. The headcount ratio dropped dramatically for East Asia and the Pacific, from a high of $29.4 \%$ in 1990 to $14.5 \%$ in 2000, but the decline was more modest in South Asia (41.5\% to $31.9 \%$ ), where the economy grew more slowly and population growth had been more rapid. Poverty as measured by the headcount ratio was higher in South Asia in 2000 than in any other region of the world, except Sub-Saharan Africa.

Poverty is basically a rural problem in South Asia. In all countries of this subregion, poverty is disproportionately concentrated in rural areas (Table 2). The headcount ratio is also higher for rural areas. Rural poverty trends vary considerably by country. In several South Asian countries, the gap between rural and urban poverty is widening over time (Table 3). These countries include India, Bangladesh, and Pakistan.

\footnotetext{
${ }^{1}$ Paper Presented at an International Conference on Ten Years of Australian South Asia Research Centre organized at the Australian National University, Canberra from 27-28 April 2004. This paper draws on IFAD. 2002. Assessment of Rural Poverty in Asia and the Pacific Region, IFAD: Rome. The current author was a principal author of this report.

${ }^{2}$ Regional Economist, Asia and Pacific Division, IFAD, Rome.
} 
Asia achieved high economic growth in the last three decades, with the gross domestic product (GDP) of East and South-East Asia growing by 7 to 10\% per annum and the economies of South Asia by 4 to 6\% (IFAD 2001). The simultaneous achievement of high economic growth rates and poverty reduction would seem to suggest a positive impact of growth on poverty reduction. Indeed, some studies show that the reduction in the headcount ratio can be attributed mainly to the growth factor (Datt 1998). However, other studies question the credibility of such findings and conclude that growth does not trickle down to the poor (Ghosh 2000).

More importantly, however, yet other studies have suggested that the "trickledown" mechanism ignores some important aspects of poverty reduction. First, the growth and redistribution components are not necessarily easy to separate, as the Gini coefficients and mean consumption are likely to co-move as in the case of Uttar Pradesh, in India, from 1959-94 (Gaiha 1998). Second, de-composition (or disaggregation of changes in poverty into growth and redistribution components) cannot capture changes in the composition of the poor and the non-poor over time. Even when an economy experiences both growth and a reduction in headcount ratio during a certain period, a substantial portion of the poor may slip into poverty (though fewer than those who escape poverty). Further, as Gaiha (1998) argues, if there is a large core of chronic poverty among those who are sick, physically weak, or belong to lower castes as in India, the effect of growth on poverty will be weak.

\section{Characteristics of Rural Poverty in South Asia}

The rural poor in South Asia are characterized by a number of general economic, demographic and social features, the most common one being landlessness or limited access to land and other productive resources. Poor rural households tend to have larger families, with higher dependency ratios, lower educational attainment and higher underemployment. The poor also lack basic amenities like piped water supply, sanitation and electricity. Their access to credit, inputs and technology is severely limited and certain constraints, such as lack of information about markets, lack of business and negotiating experience and lack of a collective organization, deprive them of the power needed to interact on equal terms with the other, generally larger and stronger market intermediaries (IFAD 2001). Cultural and social distance and discrimination are other factors that may also - at least partly - exclude the poor from markets. Low levels of social and physical infrastructure increase their vulnerability to famine and disease, especially in the mountainous and remote areas of the sub-region.

While poverty may be a transitory phenomenon for many of the poor, it is more or less a permanent one for many more ${ }^{3}$. From a policy perspective, the distinction between

\footnotetext{
3 Although the overlap between the poorest and the persistently poor is partial, a review of panel survey data points to limited economic mobility among sections of the former. In four out of six cases, $40 \%$ or more remained within the poorest quintile and the majority within the same and the next quintiles over periods of 5-8 years. As the bottom 3-4 deciles tend to be poor, large fractions of the poorest are likely to be persistently poor. (Baulch and Hoddinott, 2000, Gaiha, 2001a)
} 
transient and chronic poverty is useful for various reasons (Gaiha 2001a). First, since the chronically poor are not a negligible subset of the poor, it is important to identify who they are. Typically, chronic poverty has been found to be characterized by infrastructurally deprived remoteness, social backwardness, lack of access to education, disability and age, prolonged illness, etc. (IFAD 2002c).

These persistent poor are the main target groups for development assistance, since their upliftment is not possible without targeting. In fact, some of the criticisms of the "trickle-down" hypothesis are related to the very existence of a class of chronic or persistent poverty. Failure to identify this group of rural poor may result in directing resources to those households suffering only from temporary misfortune (i.e. errors of inclusion), and in denying them to those who are genuinely poor over the long term but temporarily out of poverty due to short-term favourable circumstances (i.e. errors of exclusion). Second, the identification of factors associated with movements into and out of poverty is useful for designing safety nets and other interventions to protect the vulnerable. Further, if this is supplemented by a clear understanding of why some households improve their wellbeing relative to others, it would assist in designing policies that promote more equitable growth.

However, it is not easy to measure transient and chronic poverty. One approach is to use income or consumption per capita or per adult equivalent as the welfare or poverty metric, and to classify the households as "always poor", "sometimes poor" or "never poor", depending on the duration of their poverty in a panel survey. In Gaiha and Deolalikar's (1993) study based on the ICRISAT panel in rural South India, the overwhelming majority of the 170 sample households $(87.8 \%)$ had been poor some time during the nine years (1975/76 to 1983/84); more than $61.3 \%$ had been poor roughly half of the time, and more than $21.8 \%$ had been poor during all nine years.

Vulnerability is another important characteristic of rural poverty in South Asia. Identification of vulnerable households is, however, more difficult than identification of poor households, since a household's vulnerability depends in large measure on the magnitude of the shock to which it is exposed. While an illness lasting several days or weeks may push a few households into poverty, an event like the death of the wageearning head would make many rural households in a developing country vulnerable to acute deprivation/poverty. Also, while households may be able to cope well with household-specific shocks in the presence of well-functioning markets (e.g. credit or labour markets) and community mechanisms, their ability to deal with community-wide shocks is much lower as these shocks affect everyone in the community (Gaiha 2001a, 2001b).

A high level of deprivation continues to plague South Asia, which, as Sub-Saharan Africa, is one of the regions with the lowest levels of social indicators (IFAD 2001). Despite the rapid improvements in infant mortality rate, life expectancy at birth and adult literacy, South Asia is still the second worst region with respect to social indicators, and it suffers from very low levels for the other human development indicators like the 
Human Development Index (HDI), the Gender Development Index (GDI) and the Gender Empowerment Index (GEM).

The level of deprivation is usually higher than what is indicated by income poverty figures. For example, a World Bank (1998a) study in India shows that, according to the 1993-94 round of the National Sample Survey, about $80 \%$ of the rural population (and $70 \%$ of the urban population) had intakes below the 2400 calories per adult per day recommended for rural areas (and 2100 calories for urban areas). This is much higher than the headcount ratio, which was $36.7 \%$ in $1993-94$. In 1993-94, the poorest $30 \%$ of India's population consumed fewer than 1700 calories per day, and the poorest $10 \%$ consumed less than 1300 calories per day.

Recent studies show that income inequality is increasing in several Asian countries that had achieved both high economic growth rates and significant poverty reduction in the last three decades. A major reason for this rising inequality is the growing disparity in economic growth arising from a concentration of economic activity in certain areas to the exclusion of others. A rich variety of experiences is revealed by an analysis of Indian states (Jha 2001). Some states that have had high rates of economic growth and enjoyed high per capita consumption show lower inequality and poverty compared to the states that are lagging behind. For example, the rural Gini for Bihar was 31.7 in 1957-58, but 38.9 in 1995-96. Bihar has also had low rates of economic growth and is among the poorest states in India. By contrast, in Punjab, the richest state, the rural Gini dropped from 32.2 to 24.4 over the same period, with poverty falling sharply. Several studies have shown that the greater the inequality the less will be the poverty-reducing effect of growth (e.g. Demery and Walton 1999).

\section{Poverty Reduction Strategy for South Asia}

In response to the Millenium Development Goals (MDGs), many multilateral and bilateral donors have accorded high priority to poverty reduction in their development assistance programmes. For example, the World Bank proposes to attack poverty in three distinct ways: promoting opportunities, facilitating empowerment, and enhancing security (World Bank 2001). The Asian Development Bank (ADB), a major donor in Asia and the Pacific, intends to pursue economic growth, human development and sound environmental management, and improve the status of people in ways that will contribute most effectively to poverty reduction - its overarching goal (ADB 1999). In this section, an effort will be made to highlight the rural poverty reduction strategy of the International Fund for Agricultural Development (IFAD), an international financial institution and a specialized agency of the United Nations with a specific mandate of reducing rural poverty through agricultural and rural development.

IFAD in its Rural Poverty Report, 2001 has argued that, to be successful, poverty reduction policies must focus on rural areas where $75 \%$ of the poor work and live and where more than 50\% are expected to continue to do so even by 2025 . It further emphasized that the rural poor need legally secure entitlements to assets (especially land and water), technology (particularly to increase the output and yield of food staples), 
access to markets, opportunities to participate in decentralized resource management and access to micro-finance. It concluded that such policies will not only promote economic growth but would also help to reduce poverty. It therefore called for a pro-poor policy environment and an allocation of a greater volume of resources targeted to the poor with greater effectiveness.

Building on its Rural Poverty Report 2001, IFAD developed its Strategic Framework in 2002, which is conceived as part of the broad global commitment to achieving the MDGs by enabling the rural poor to overcome their poverty, as perceived by the poor themselves (IFAD 2002a). The Strategic Framework has three major objectives: (a) strengthening the capacity of the rural poor and their organizations, (b) improving equitable access to productive natural resources and technology, and (c) increasing access to financial services and markets. Its rural poverty reduction strategy for South Asia envisages a focus on the less favoured areas - the remote uplands and mountains, the marginal coastal areas and the unreliably watered drylands (IFAD 2002b). Within this geographical focus, the strategy concentrates on women, indigenous peoples ${ }^{4}$ and other marginalized groups such as the landless and the dalits (lower castes in India and Nepal). In focusing on these niche areas, the strategy intends to ensure complementarity with the poverty reduction initiatives of governments and other donors in areas such as health, education and infrastructure. A brief description of the strategy follows.

\section{A. Development of Less-Favoured Areas}

In the past, development strategies in South Asia, as in other sub-regions of Asia, have tended to concentrate on irrigated and high-potential areas, in order to expand food supply, stimulate growth and reduce poverty. The success of this strategy in triggering off the Green Revolution in many South Asian countries was impressive. Between 1970 and 1995, cereal production in India increased by $88 \%$, entirely as a result of yield increases, as cereal area did not increase during this period (IFAD 2002c). Other countries in South Asia also did very well in cereal production, as both cereal yield and area increased. As a result of these cereal production gains, per capita calorie consumption increased by about $15 \%$ in India. In other countries of South Asia, however, calorie consumption per capita rose only marginally (4.1\%), as population growth was very high.

However, this strategy resulted in neglect of less-favoured areas where a large proportion of the rural poor live. It is estimated that $40 \%$ of Asia's poor live in lessfavoured areas ${ }^{5}$. This very rough estimate is supported by more precise estimates for India and China (Rosegrant and Hazell, 2000). Despite outmigration to areas of more

\footnotetext{
${ }^{4}$ Indigenous peoples are variously known as ethnic minorities, tribal groups and scheduled tribes. The terms refer to social groups with a social and cultural identity that is distinct from the dominant groups in society and that makes them vulnerable to being disadvantaged in the development process.

${ }^{5}$ According to a report prepared by the Technical Advisory Committee of the Consultative Group on International Agricultural Research, 550 million ha of land currently used for agricultural purposes in Asia can be classified as marginal and another 340 million ha are sparsely populated arid lands. In contrast, there are only 305 million ha of high-potential or favoured land. Of the 633 million rural poor in Asia in 1988, about 263 million (40\%) lived in the less-favoured areas.
} 
rapid growth, the population in these less-favoured areas has grown. However, this growth has not been matched by yield increases and, as a result, a worsening of poverty has been accompanied by widespread degradation of natural resources (e.g. soil erosion, deforestation and loss of biodiversity) through the expansion of the cropped area. This in itself is a strong enough justification for calling for a redirecting of development resources to these areas. However, this argument is further reinforced by highly favourable production effects and the absence of a trade-off between poverty reduction and higher production in these resource-poor regions.

In a study based on Indian data (Fan and Hazell, 2000), the districts were divided into irrigated, and high - and low - potential rainfed areas. The findings showed that total factor productivity (TFP) growth had slowed in irrigated areas, from nearly 3\% p.a. during the 1980 s to a little over $2 \%$ in the 1990 s, and that it had remained unchanged at about $4 \%$ for the high-potential rainfed areas. However, TFP accelerated strongly in the low-potential rainfed areas, from about $1.5 \%$ in the 1980 s to about $3 \%$ per annum in the 1990s.

The study found, for example, that roads not only contribute directly to agricultural production but also influence the adoption of high-yielding varieties and investment in irrigation, variables that in turn also have an impact on agricultural production. Further, technology and infrastructure variables have an impact on rural poverty (i.e. the headcount index) through their effect on agricultural production, wage rate and terms of trade. The study concluded that for every investment, the highest marginal impact on production and poverty reduction occurs in rainfed areas, while irrigated areas rank second or last. Moreover, many types of investments in low-potential rainfed areas yield some of the highest production returns, and all types of investments except markets and education have some of the most favourable impacts on poverty.

The study did not however explicitly consider differences in the costs of providing infrastructure in different types of areas. For example, roads are costlier to build in remote mountainous areas. One issue that consequently arises is whether or not the evidence conclusively favours channeling a larger share of public investment to lowpotential areas. However, there is some evidence from India that suggests that the unit costs of providing infrastructure are similar across states, notwithstanding the considerable diversity in the proportions of irrigated and rainfed areas. While an even more careful assessment is clearly needed to firmly make the case for favouring lowpotential areas, it can be legitimately claimed on the present evidence that the potential of larger investments in such areas, for poverty reduction as well as production returns, cannot be underestimated or overlooked.

Although their soils are marginal, the uplands and mountain areas of South Asia offer huge opportunities for economic development on other fronts: as sources of water, power and biological diversity, valuable minerals and a wide variety of forest and agricultural products. Opportunities for investment include forestry and agroforestry, harvesting of medicinal plants and the environmental-friendly production of high-value 
products such as organic foods, morels and fine wool. Similarly, these areas have some of the world's most pristine ecological settings, eminently suitable for eco-tourism.

In view of their high incidence of poverty, political and economic marginalization, and their development potential, IFAD has accorded high priority to the development of less-favoured areas. The specificities of these areas and their populations call for innovative programme design and implementation arrangements. Due to their remoteness and diversity, IFAD will give priority to the development and application of decentralized, participatory and iterative approaches to programme design and implementation. This is expected to ensure both sensitivity to local conditions and increased beneficiary commitment, thus enhancing the sustainability of results.

Although environmentally sustainable development will be promoted in these areas, every effort will be made to link the vast potential of such areas to domestic and international markets. Just as essential as social concerns is the identification of marketable products and the introduction of suitable technologies to exploit their possibilities. These two aspects will provide the basis for enhancing the capabilities and incomes of the rural poor on a sustainable basis.

\section{B. Enhancing Women's Capabilities in Order to Promote Social Transformation and Agricultural Production}

South Asia stands out for a startling inequality in gender relations. For example, in India, over $90 \%$ of the rural women workers are unskilled and $90 \%$ of them work in the informal/ unorganized sectors (IFAD 1999a). The wage rates for women in agriculture are $30-50 \%$ less than for men and female casual labourers have the highest incidences of poverty of any occupational category, male or female. In Bangladesh, the burden of poverty falls disproportionately on women, whose nutritional intake averages at only $88 \%$ that of men (IFAD 1999b). Only $29 \%$ of women are literate compared to $45 \%$ of men. In Nepal, a relatively high proportion (28.7\%) of rural women has a body mass index below the cut-off point, an indication of chronic energy deficiency (IFAD 2000). The literacy rate among rural women in 1995/96 was only $17.2 \%$ compared to $51.1 \%$ for rural men. The severity of poverty is usually higher for women and they face greater hardship in lifting themselves (and their children) out of the trap of poverty. Women have fewer opportunities than men due to a number of gender biases within their societies, including unequal opportunities for access to education, employment and asset ownership. Without education, women enter a vicious circle marked by fewer opportunities for employment, early marriage, poor child health care, limited knowledge of contraceptive use, and high fertility.

Deprivation is a major factor of poverty and the extent of deprivation of the women in South Asian countries is colossal. Yet, it is reported that, where both men and women control resources, women tend to spend their incomes mostly on family basic needs while men spend a greater share on personal needs (Mencher 1989). This is particularly true for the poorer households. An early study from Kerala, India, revealed a positive correlation between the consumption of children and women's outputs from home gardens or income 
under their control (Kumar 1978). Therefore, women's access to and control over resources is extremely important for their wellbeing and especially that of their children. There are significant inequalities in men's and women's access to private resources throughout the region. Agricultural land - the single most important production resource in the rural areas - is mostly owned by men.

The extent to which national and international organizations are able to make an impact on poverty in South Asia in the coming decades will depend on the extent to which they are able to alter gender relations. There is strong evidence to show that enhancement of women's role as agents of change is the key strategic policy for changing gender relations and rebuilding societies with greater social and economic justice. The effect of such a policy extends beyond the household or even the community of which women are a part. Development literature recognizes the close connection between the education of women and elimination of some of the worst expressions of poverty, e.g. high infant and child mortality rates.

Some countries in South Asia have adopted legal measures to enhance women's representation in village committees. IFAD's own experience has been that the representation of women initially tends to be largely nominal, but that, over time, women do begin to exercise the powers to which they have gained access, including as heads of committees. As this occurs, many studies contain reports of less corruption in the use of public funds and of higher spending for family and child welfare, education activities, etc.

In seeking to transform gender relations in order to build a strong base of norms that promote poverty reduction, one needs to look at interventions that have ripple effect possibilities. Micro-finance is one such example of a strategic gender intervention with effects across many areas of women's existence. It is a successful innovation in enabling assetless women to obtain access to rural finance services, an important innovation with which IFAD has long been associated. It is the Fund's experience that the transformational role of microfinance has occurred in many traditional cultures endorsing women's seclusion and lack of property. IFAD continues to work with governments and other stakeholders in modifying the policy environment in order to expand outreach to poor women. In formulating strategies for reducing gender inequality, IFAD will take into account the disparities within the sub-region and the individual countries.

\section{Enhancing the Capabilities of Indigenous Peoples and Other Marginalized Groups}

It is estimated that more than two-thirds of the world's more than 300 million indigenous peoples live in Asia. In South Asia alone, there are more than 100 million indigenous people. The features that distinguish them from the lowlands populations include a strong emphasis on clan structures and ethnicity bonds, a strong sense of identity and a higher position of women. Whereas the lowlands societies are essentially patriarchal, gender relations among the forest dwellers and the highlanders are more 
gender-positive, ranging between matrifocal and matrilineal systems and various forms of transition to patriliny.

Incidence of poverty is very high among these people. For example, out of the ten regions of India with the highest incidence of poverty four are inhabited by indigenous peoples (known as "scheduled tribes"). In 1993-94, when slightly less than $40 \%$ of all Indians were below the poverty line, the proportion was $54 \%$ for the scheduled tribes (IFAD 1999a). The tribals of India accounted for only about $8 \%$ of the total population, but $40 \%$ of the internally displaced population, another major characteristic of poverty.

In Bangladesh, more than $50 \%$ of a total of 1.2 million tribals live in the Chittagong Hill Tracts, and their lives have been severely disrupted in the recent past (IFAD 1999b). For example, the construction of the Kaptai hydroelectric project rendered some 100000 of them homeless and submerged about 54000 acres, equivalent to $40 \%$ of the land suitable for intensive cultivation. Some of the displaced families who had settled in the lower hills were displaced again after 1975, by programmes for the resettlement of persons from the lowlands.

The indigenous people tend to get neglected even by the international community or are being persistently marginalised by national governments themselves and have been hit hardest by this process of de facto exclusion and marginalization. This is so because they are generally marginal to the growing national and global networks of capital. Unfortunately, the economic and political marginalization of the indigenous peoples have made the many South Asian uplands home to violence ${ }^{6}$.

There is a growing awareness among policy makers and funding agencies that the historical marginality of these areas may largely be a function of ignorance as to the magnitude of their true worth. Also, the potential of indigenous peoples as 'stewards' of national and global natural resources and biodiversity is increasingly acknowledged (IFAD 2003). The World Summit on Sustainable Development (WSSD) in Johannnesburg, for instance, reaffirmed the 'vital role of indigenous peoples in sustainable development'. Indigenous peoples in general and indigenous women in particular have rich traditional knowledge systems (ecosystem management and technologies, medicinal plants, local crops) that are increasingly attracting the attention of commercial interests, yet they rarely get a share of the benefits.

As most indigenous peoples live in marginal areas where property rights are ill defined, secure access to land, forests and water is a major issue. It is important to give legal recognition to their collective, intergenerational rights to the territories that they have always inhabited and the natural resources that they have always used. For them, land is not only an asset for livelihood security but also the context supporting their continuing existence as indigenous peoples. Among the most important assets in the upland areas are the forests and their biological diversity. Indigenous peoples have traditionally had a very intimate knowledge of these rich resources and yet their

\footnotetext{
${ }^{6}$ Marginalization connotes nearly complete exclusion from the mainstream of economic and political activities.
} 
stewardship of biodiveristy and their skills and interest to manage are seldom recognised. If poverty reduction is our goal, then today there is an urgent need to make the forest dwellers co-owners of the forests and to reward them for the environmental services they provide to the world at large.

In selected countries, IFAD-funded projects focus on assisting indigenous peoples in gaining access to land and related resources. This is done by supporting the participatory mapping of territorial boundaries, by assisting in the preparation and implementation of land management plans and providing required capacity building. They also provide support in strengthening existing indigenous peoples' organizations and governance systems; promoting inclusion of the most marginalized groups (e.g. women and youth); and empowering indigenous women so that they can meet both their practical and strategic needs.

Based on its experience in the region, IFAD has promoted the following strategic interventions for rural poverty reduction in South Asia:

\section{A. Enhancing Access of the Poor to Productive Resources}

A major factor of rural poverty is landlessness and limited access to land. The extent of landlessness is very high in South Asian countries like India (22\%), and Bangladesh (49.6\%). Also, landlessness is increasing over time in these countries. In Bangladesh, for example, the percentage of landless households (defined as those with less than $0.2 \mathrm{ha}$ ) in total households was $46 \%$ in 1988 but $49.6 \%$ in 1995, and their share of total land had declined by nearly half a percentage point (Hossain 1996). Most of landless in rural areas are poor and work as agricultural wage labourers. Marginal farmers and tenants are found everywhere in the sub-region but they predominate in countries like Bangladesh, India, Nepal and Pakistan.

Security of tenure, if properly implemented, provides incentives for long-term inverstment. This is corroborated by IFAD's experience in India (IFAD. 2002c). The Orissa Tribal Development Project in India funded by IFAD provides a very concrete example of the impact of tenure reform on natural resource management (NRM) policy. The project represented the first occasion in Orissa where land titles were provided to tribal groups for land above 10 degrees in slope. Land occupied by tribals became transferrable to women in the form of inheritable land titles (donga pattas) in perpetuity. Project supervision missions pointed out that such land titling led to major improvements in natural resource management due to the incentives derived from clear property rights. Comparisons between project areas where land titling had been granted, and adjacent open access areas illustrated dramatic differences in land quality. The positive impact this project has had on NRM has been a central feature of the policy dialogue with the Government in the preparation of a second phase project in Orissa. It is hoped that the policy will be expanded across the entire state in the second phase.

Similarly, the Andhra Pradesh Tribal Development Project also in India, has contributed significantly to a major shift in NRM policy. Through building community 
NRM institutions and supporting a village based NRM extension training programme, where villagers act as animators in resource planning at the local level, the project demonstrated that tribal groups were successful in managing natural resources at the community level. This experience was central to the decision by the Government of Andhra Pradesh to support a virtual surrender of sovereignty of land to tribal groups. India - Land rights as an incentive for NRM Both these projects in India have attempted to foster community involvement in developing the natural resource base with the microwatershed as the planning unit. This approach is usually not realisable without: (i) secure land rights of the community, (both individual and community land rights); and, (ii) the active participation of the community in planning.

In many parts of South Asia, the rural poor rely heavily for their livelihood on common property resources (CPRs) available through open-access systems. Examples include irrigation water, forests, rangelands, fisheries, wildlife and flora. In recent years, there has been an increasing trend towards devolution of control over natural resources from central governments to local communities. Devolution has emphasized the protection of resources to be used by all, rather than poverty reduction through the securing of livelihoods for the poor. A second problem with CPRs is that they are almost always open to any and every one, without regulation or restrictions. As a result, many rangelands, water bodies and forests are heavily degraded or suboptimally used due to lack of or improper investment - either in infrastructure or yield enhancement.

IFAD has experimented with a range of approaches aimed at enhancing access of the poor to CPRs and to improving the productivity of these resources. Two important experiences in South Asia concern the Oxbow Lakes Small-Scale Fishermen Project in Bangladesh and the Hills Leasehold Forestry and Forage Development Project in Nepal, where CPRs (lakes and degraded forests, respectively) were leased to the poorest people in surrounding villages. Both cases demonstrated that 'social fencing' can be effective in safeguarding the benefits of investments and that sharing of income on the basis of labour contribution can preserve the principle of equity. In the Oxbow Lakes project, adequate investment support from donors allowed many formerly landless labourers and poor fishermen and women to raise their incomes to the level of mid-level farmers in the community. Small fishponds leased to groups of women contributed both to income increases and enhancement of their overall status within the family and society. In the case of the Nepal project, fodder was grown on hill slopes, generating substantial livelihood benefits for the poor, including women.

\section{B. Enhancing Access of the Poor to Sustainable Agricultural Technologies}

Green revolution technologies-based on high-yielding varieties of cereal crops, irrigation and chemical fertilizers-increased foodgrain production in South Asian countries in the 1970s and 1980s, mainly through productivity growth. By keeping food prices down and employment up, the technology contributed to rural poverty reduction in many countries of the sub-region. However, there has been little progress in developing appropriate technologies for less favoured areas, e.g. the drylands and the uplands and mountainous areas. Rice yields in rainfed areas are only half of those in irrigated areas, 
with even lower yields in the upland and deepwater areas (Rosegrant and Pingali 1991). Technological breakthroughs have not been made for crops like sorghum, millet and cassava, the staple foods grown by the poor, consumed by the poor and grown on less productive marginal lands. Only a quarter of international agricultural research resources has been devoted to marginal lands and national research resources have also been used mostly on tradables like rice, wheat and maize (UNDP 1997). Research input has been high on rice, maize and wheat and world average yields have more than doubled over the past 20 years, while the world average yield of millet and sorghum increased by only $15 \%$. This, coupled with the decreasing arable land per capita, has raised serious food security concerns for the poor. Available data show that the arable land per capita decreased in all Asian countries, except Malaysia, between 1979 and 1996 (World Bank 1998b).

Given the limitations of high-input agriculture and organic farming, in less favoured areas of South Asia, sustainable or regenerative agriculture holds enormous promise for yield increases and environmental protection. It involves the identification, development and establishment of resource-conserving technologies that either conserve/improve existing on-farm resources (e.g. nutrients, pest predators, water, and soils) or introduce new elements (e.g. nitrogen-fixing crops, agro-forestry, water harvesting structures, new predators). Until recently, few had realized the potential for a regenerative or sustainable agriculture that is situated somewhere between organic and very high input agriculture (Pretty 1995).

In contrast, regenerative agriculture, if profitable, would be immediately available to all farmers, as it does not rely on consumer preference. Pretty (1995) has shown that in the complex and diverse agricultural systems, where external input use is low or nonexistent, there is a considerable evidence for the impact of sustainable agriculture. In such systems, two to three-fold increases in yields have been achieved with the communitywide adoption of resource-conserving technologies and practices (Table 4). Crop yields have increased without the use of fertilizers and pesticides in programmes focusing on soil and water conservation, land rehabilitation, nutrient conservation, raised field agriculture, green manuring and integrated pest management. For upland and mountainous areas also, a number of regenerative technologies are now available for farmers' use.

The major emphasis of IFAD support for the development of new technologies is that they should yield more per unit of input, and be more labour-intensive, adjustable to the seasonal demands for labour and food, robust against climatic risks, pro-poor in terms of the poor's choices, and less material cost-intensive (Rahman and Westley 2001). ${ }^{7}$ Since household food security and malnutrition are still major concerns in these areas, research to develop technologies that stimulate increased productivity of staple foods must be pursued. IFAD will promote the development and dissemination of sustainable

\footnotetext{
${ }^{7}$ Since 1979, IFAD has committed more than US\$ 100 million to research programmes of CGIAR centres, focusing on input-output relations in marginal rainfed environments, institutions and incentives to maximize returns and conservation for smallholder assets, and building local capacity for participatory research (IFAD 2001).
} 
or regenerative technologies uniquely suited to the complex and diversified agricultural systems of less favoured areas.

\section{Building and Strengthening Organizations of the Poor}

IFAD's approach lays strong emphasis on building and strengthening institutions for the rural poor. This involves supporting decentralization initiatives to bring decisionmaking closer to the rural poor, promoting better governance, supporting farmers' and water users' groups, and working with civil societies in general to create enabling conditions for the poor to help themselves (Rahman and Westley 2001). In most cases, such support slows down the implementation of projects, as institution building in a democratic and transparent way is not a quick process.

Strengthening institutions also means pursuing a delicate balance between the rich and the poor, as most conventional institutions are dominated by the rich. In most rural societies it would be practically impossible to ignore or by-pass the traditional power structure. The ruling elites can be by-passed if they are isolated and there is sufficient mobilization of the poor to secure their rights. It is sometimes necessary and productive to convince the well-off that they, too, would benefit from transferring resources to the poor. For example, the difficulties the well-off face in private fencing of common property resources, whether of water bodies or forests, and thus in securing their investments can itself be a powerful factor in persuading them to agree to a redistribution. There are projects in which both the poor and the rich gain by agreeing on, and delivering, a strategy. There are also examples where the poor have benefited by uniting with some of the rich in a coalition to raise their income. Whatever the options are for the poor to enrich themselves by influencing institutions, the crucial issue is: how can institutions, initially controlled by the rich and strong, be run mainly in the interests of the majority who are poor? The rich - as self-insurance against events that do not hit only the poor, fear of rebellion or even altruism - can sometimes transcend crude self-interest and support some forms of pro-poor distribution, e.g. provide basic health care or social safety nets (IFAD, 2001). In such cases, much depends on whether the poor use their resources and power jointly, or are divided by distance, caste, ethnic group or gender.

The Oxbow Lakes Small-Scale Fishermen Project in Bangladesh and the Hills Leasehold Forestry and Forage Development Project in Nepal, described above, are examples of successful redistribution of community assets to coalitions of the poor. The project in Nepal selects the marginalized sections of the community, families below the poverty line, women and deprived minority ethnic or tribal people, and forms them into groups that are then given a 40-year lease of designated forests - which often amounts to a lease for life.

It was found that targeting marginal groups would not produce positive results unless the agreement of the whole community was secured. These leases were given on what had been community land used by both the richer and the poorer farmers. Considerable time was spent persuading first the officials and then the rest of the community - in particular the village leaders - that the project would benefit everyone 
and not just the leasers. In the same way, in the Oxbow Lakes Small-Scale Fishermen Project in Bangladesh, the local elite, who had been unable to substantially benefit from their investments (due to poaching by all around the lake), could see that fish culture by the poor increased local availability of fish, thus reducing prices and ensuring fresh produce.

In many countries, development programmes have in effect been captured by vested interests, with the active collusion or passive acquiescence of state elites (IFAD, 2001). This, happens in the absence of people's organizations that actively promote coalitions of the poor. Important factors that promote coalitions of rural poor were identified in a review (Gaiha and Kulkarni, 1999). Where there has been cooperative action in the past, the chances of building cooperation among the poor are high. Cooperative action may be associated with the shared norms of fairness, reciprocity and trust in a community. It is debatable whether such norms can be observed in vertical social networks involving people of different status and power. There is some evidence that if the gains are large, even socially heterogeneous groups can come together (Seabright, 1997). However, where there are severe economic inequalities in a given society, local organizations are captured by the rural elite.

IFAD's experience in Bangladesh, India and Nepal show that it is possible to create trust where strong traditions of collective action did not exist before. This depends on secure, long-term user rights to resources and incentives to cooperate, in the form of the substantially higher incomes that could result. In designing and implementing projects involving CPRs, IFAD will promote systems of equity in access or income and cost, including labour sharing, along with monitoring by group members and democratic rotation of leadership.

\section{Enhancing Access of the Poor to Financial Resources}

Although banking services have expanded rapidly in rural areas of South Asia in recent years, the majority of rural poor have not been able to benefit from these services. Studies have shown that non-governmental organizations have considerable potential in serving the poor better (Sinha 1998). Following the success of the Grameen Bank in Bangladesh and other similar experiences, microfinance institutions tend to rely more on peer group monitoring and joint liability to overcome the screening, monitoring and enforcement problems commonly encountered by formal lending institutions. These programmes deliver small loans to poor borrowers, mostly women organized into small self-help groups (SHGs), combined with accessible deposit facilities and much greater attention to risk management. Thus they aim to increase their incomes and smooth the consumption.

IFAD views microfinance programmes as a vehicle with potential to build local institutions and empower the poor, especially women. Facilitating women's access to independent income and financial services, providing cohesive structures of support through solidarity groups, and promoting self-employment, all enhance women's status in 
the family and their control over family resources. Such schemes promote the family's well-being, thus proving to be an important strategy to reduce poverty.

The positive effects of micro-finance are today well acknowledged. A study by Hashemi et al (1996) suggested that "women's access to credit contributed significantly to the magnitude of the economic contributions reported by women, to the likelihood of an increase in asset holdings in their own names, to an increase in their exercise of purchasing power, and in their political and legal awareness. Furthermore, access to credit was also associated with higher levels of mobility, political participation and involvement in 'major decision-making' for particular credit organizations” (Kabeer, 1999).

Women's social transformational roles have also been observed in several IFADfunded projects in Asia. In IFAD-funded Andhra Pradesh Tribal Development Project, self-help groups (SHGs) of women took up contracts for local construction and, with the help of supportive bureaucrats, were instrumental in the elimination of contractors for such works in all tribal areas of the state. In the IFAD-funded Maharashtra Rural Credit Project, once they had become well established, women's groups, took up numerous social issues. The curtailment of alcoholism was one. Other issues were to demand and force improvements in the provision of social services, like drinking water, bus services, and so on. In the IFAD Tamil Nadu Women's Development project, women's groups in villages affected by extreme discrimination against girl children took measures to oppose female infanticide. More recently, federations of SHGs in the Andhra Pradesh Tribal Development Project have taken on multiple functions in addressing social and administrative issues at the block and sub-division levels. They have taken up issues like construction of toilets, repair of roads, improvement in drinking water and electricity supply.

However, growing evidence indicates that these programmes may not have reached the extremely poor. Lack of access to land and a homestead was identified by an IFADsponsored study as the major factor in exclusion of the poorest (Rahman 1999).

\section{E. Promoting Rural Non-Farm Employment}

The rural non-farm economy plays a significant role in providing employment and income for the poor in rural areas. As population pressure grows in land-scarce Asian developing countries, growth in agricultural production cannot absorb increasing rural labour force in agricultural employment (IFPRI 2001). The urban industrial sector cannot grow fast enough to absorb the surplus labour released from agriculture. This leaves the rural non-farm sector to absorb the population released from agriculture and unable to be absorbed in the urban industries. The non-farm economy accounts for 40 to $60 \%$ of total national employment and the rural non-farm economy accounts for 20 to $50 \%$ of total rural employment (ADB 2000).

Many studies indicate that the rural non-farm sector growth based on growth linkages to successful farmers and their employees, who demand booming services 
(construction, trade, transport), has a better chance to cut poverty (IFAD 2001). Most traditional rural non-farm sector participation, reflecting family skills, land shortage, or the need to diversify against seasonal employment or annual drought risk, is linked to poverty, so should not be neglected; but modern, linkage-based rural non-farm sector is a more promising way out of poverty (e.g. Mellor 1976, Hazell and Ramasamy 1991). Studies of the rural areas of Asia reveal strong linkages between agricultural growth and the rural non-farm economy, which tends to follow agricultural growth and depends mostly on local and regional demand (e.g. Mellor and Lele 1972, Mellor 1976).

IFAD has supported rural micro and small enterprises (RMSEs) as specific components or subcomponents of rural development projects in order to enhance employment and income-earning opportunities and empower the rural poor, particularly women (IFAD 2004). In 2003, a third of the Fund's active investments in small-scale rural enterprises in Asia and the Pacific included RMSE-related initiatives.

IFAD seeks to promote RMSEs by supporting interventions in four different areas: facilitating their access to financial and non-financial service; improving their access to markets; and creating a supportive institutional environment. Microfinance has been a principal means of advancing non-farm self-employment and rural enterprises in the Fund's projects in various countries of Asia and the Pacific region. Rural microfinance alone, however, cannot promote an enterprise to the growth-oriented level, nor can it help borrowers graduate from microfinance schemes to direct borrowing from banks. For RMSEs to move beyond the subsistence/livelihood level, training, skills, production technologies and market linkages are crucial. Rural people also need access to markets, both as producers and consumers, since the ability to operate in local, national and export markets (regional and international) is instrumental in guaranteeing the viability of RMSEs. Although the Fund's services in these three areas (financial, nonfinancial services, and access to markets) are crucial to fostering RMSEs, they cannot be effective in a policy and institutional vacuum. Governments need to create a conducive framework for the development of the non-farm sector, and IFAD can assist them in adopting the prudent policies needed.

Self-employment schemes such as those promoted by micro-finance programmes, typically enable the poor to acquire income-generating assets by providing access to credit, marketing and other inputs. In contrast, wage employment schemes create wage labour opportunities for the poor, mainly on public works projects. Many developing countries have used such schemes to deal with situations (such as famine and droughts) marked by widespread but transitory unemployment in rural areas. In recent years, countries like India and Bangladesh have included employment creation through rural public works (RPW) programmes at the core of their poverty reduction strategy. Other justifications for RPWs include their ability to reduce negative externalities (.e. afforestation) and their self-targeting nature, which could effectively help to reduce inequality or poverty. They could also improve the economic and social positions of the poor through participation (Dreze and Sen 1989). 
However, it is very important for policy-makers to recognize both the strengths and the shortcomings of RPWs, and to make the schemes as efficient as possible in the early stages. The case studies in rural India show that mis-targeting is likely to result due to shortcomings of design and implementation. If the self-targeting method is applied, the wage rates of the scheme and the work requirements have to be such as to attract only the poor and special attention must be given to selecting relatively disadvantaged areas. For the poor, inflexibility of timing, delayed payment of wages and even the opportunity costs of participation are non-negligible. It is particularly important to simplify the procedure in ways that can make the scheme attractive to the poor.

Whether RPWs can be substitutes or complements for micro-credit schemes is of interest for the policy-makers, particularly as micro-credit schemes often fail to reach the poorest. If the poorest households cannot or are not willing to take loans for fear that unstable income flows may prevent them from repaying, a well-targeted RPW component could complement micro-credit by securing income flows. If some of the poor who are excluded from any credit scheme are vulnerable to risk, RPWs could serve a complementary role, again by mitigating income fluctuation. This is the approach adopted in China through the partnership and collaboration between IFAD, the World Food Programme and the Government of China (IFAD 2002c).

\section{F. Enhancing Access to Markets}

Less-favoured areas and disadvantaged groups (women, indigenous peoples) face many problems related to market access. An important problem is personal immobility, which frequently impairs responses to changing incentives (IFAD 2001). Rural poor in remote areas find access to markets restricted by high costs and by their lack of knowledge of market mechanisms, a consequence of lack of information and organization. The situation is further affected by the structure of the markets themselves, the limited market intermediaries and asymmetrical market power (Table 5).

Both remoteness and poverty reduce access to markets, increasing both the physical costs in reaching them and the costs of overcoming imperfect and often discriminatory institutional mechanisms. Women and other disadvantaged groups are particularly affected by these constraints.

Although it is recognized that trade liberalization plays an important role in promoting economic prosperity, supply responses are conditioned by infrastructural support such as roads and communications in less-favoured areas. Studies have shown that trade liberalization has not influenced the lives of the poor in remote or inaccessible areas; in fact, it can erode many of the comparative advantages of such areas (Jodha, 2001). For example, trade liberalization and the opening up of domestic markets to imports can erode the comparative advantage of mountain areas in the production of certain high-value commodities that can now be replaced by cheap imports. In response to high external demand and profitability, globalization introduces new incentives, technologies, infrastructure and support systems. As a result, man-made facilities are created for production in the plains, undermining the comparative advantages held earlier 
by mountain areas. In India, for example, products such as off-season vegetables, crop seeds, honely, mushrooms, flowers and herbs can now be produced more cost effectively, and in large quantities, in greenhouses in the plains of Punjab, substituting the production of such commodities in the mountain areas of Himachal Pradesh. Trade liberalization and the opening up of imports will further erode the comparative advantages of mountain areas in the production of high-value commodities, as they will not be able to compete with cheap imports on domestic markets. For example, it is difficult for apples from the mountain areas of India to compete, in the domestic market, with imports of apples from developed countries.

Lack of resources and skills prevent mountain and upland people from participating in - and gaining from-opportunities offered by trade liberalization, which leads to their exclusion from the global economy. The poor in such areas need support in enhancing their access to skills, information and resources. For example, emerging experience in some countries demonstrates that community-based information and communication technologies can help these small producers obtain information on prices, innovative production methods and markets.

IFAD's approach is to open up opportunities for the poor through the development of infrastructure and market institutions (Rahman and Westley 2001). The strategy is to follow a complementary approach which will address not only the physical aspects of market access but also the institutional aspects. It tries to ensure the development of competitive markets, while at the same time safeguarding the poor from the risks associated with globalization and trade liberalization. This is why IFAD emphasizes a degree of food security to ensure the poor's security and enthusiasm for participating in commercialization.

\section{Concluding Remarks}

Since poverty in South Asia is a massive problem, its sustained reduction will be crucial in achieving the Millennium Development Goal of halving poverty by the year 2015. Poverty in this sub-region is basically a rural problem, as the overwhelming majority of the poor live and work in rural areas. This paper argues that, for rural poverty reduction, key interventions are enhancing access of the poor to productive resources (land, water, forests), technology, financial services, and markets, and to strengthen the capacity of the rural poor and their organizations. Given the geographical and social concentration of poverty among certain areas and groups of rural poor, it also argues that rural poverty reduction efforts should focus on the less-favoured areas (remote uplands and mountains, marginal coastal areas and unreliably watered drylands) and on socially marginalized groups such as women, and indigenous peoples. 


\section{References}

Ahuja, V., B. Bidani, F. Ferreira and M. Walton. 1997. Everyone’s Miracle: Revisiting Poverty and Inequality in East Asia. World Bank, Washington, D.C.

Asian Development Bank (ADB). 1999. Fighting Poverty in Asia and the Pacific: The Poverty Reduction Strategy. November 1999, Manila.

ADB. 2000. Rural Asia: Beyond the Green Revolution. Manila.

Bardhan, P. 1996, “Decentralised Development”, Indian Economic Review, vol. XXX.

Baulch, B. and J.J. Hoddinott. 2000. Economic Mobility and Poverty Dynamics in Developing Countries. Journal of Development Studies, Vol. 36.

Datt, G. 1998. Poverty in India and Indian States: An Update. FCND Discussion Paper No. 47, International Food Policy Research Institute.

Demery, L. and M.Walton (1999) “Are Poverty and Social Goals for the $21^{\text {st }}$ Century Attainable?”, IDS Bulletin, vol. 30, no.2.

Dreze, J. and A. Sen. 1989. Hunger and Public Action. Oxford University Press, Oxford.

Fan, S. and P. Hazell. 2000. Should Developing Countries Invest More in Less Favoured Areas? Economic and Political Weekly, April 22.

FAO. 1999. Securing Livelihoods of Indigenous and Marginal Upland People Through Sustainable Management of Farm and Forest Resources, Working paper prepared for IFAD Special Programme for Asia, Rome.

Gaiha, R. 1989. “Are Chronically Poor Also the Poorest in Rural India?” Development Change, 20.

Gaiha, R. and Deolalikar, A. 1993. "Persisent, Expected and Innate Poverty: Estimates for Semi-Arid Rural South India, 1975-1984.” Cambridge Journal of Economics, 17.

Gaiha, R. 1998. Do Anti-Poverty Programmes Reach the Rural Poor in India?. Mimeo. Faculty of Management Studies, University of Delhi, New Delhi.

Gaiha, R. and V. Kulkarni. 1999. Policy Reforms, Institutions and the Poor in India, Contemporary South Asia, vol 8 (1), pp. 7-28).

Gaiha, R. 2001a, International Development Goal of Poverty Reduction: Implications for IFAD, Rome: IFAD. 
Gaiha, 2001b: Decentralisation and Poverty Alleviation in Asia, a study prepared for Asian Development Bank (Mimeo).

Ghosh, A. 2000. "Whither the Trickle Down Effect of Growth?” Business Line, March 21.

Government of Bangladesh. 1996. Draft Country Position Paper: Bangladesh for the World Food Summit, 13-17 November 1996.

Hashemi, S., S. Schuler and A. Riley. 1996. Rural Credit Programmes and Women's Empowerment in Bangladesh. World Development, Vol. 24, No. 4.

Hayami, Y., Ouisimbing, A.R., and Adriano, L.S., 1990. Towards an Alternative Land Reform Paradigm: A Philippine Perspective. Ateneo de Manila University Press.

Hayami, Y. 1991, “Land Reform”, in G. Meir (ed.) Politics and Policy Making in Developing Countries, San Francisco, International Centre for Economic Growth.

Hazell, P. and C. Ramasamy. 1991. The Green Revolution Reconsidered: The Impact of High-yielding Rice Varieties in South India. Johns Hopkins University Press: Baltimore.

Hooke, G. et al. 1999. Agriculture in Times of Crisis: Impacts in South-East Asia of the Economic Crisis. A Report Commissioned by the Australian Agency for International Development (AusAid) from Hassall and Associates International.

Hossain, M. 1996. Rice Research, Technological Progress and Impact on Rural Economy: The Bangladesh Case, Paper Presented at the International Conference on the Impact of Rice Research, 3-5 June 1996, Bangkok, Thailand.

Huang, Jikun and Scott Rozelle. 1999. The Role of Non-Farm Enterprises in Rural Poverty Alleviation in Asia: The Case of China. Paper Prepared for IFAD Regional Poverty Assessment for Asia and the Pacific.

International Food Policy Research Institute (IFPRI). 2001. Development Opportunities in the Non-Farm Sector: Review of Issues and Options in Asia. Main Report of the Study Sponsored by IFAD, Rome.

International Fund for Agricultural Development (IFAD), 1992, The State of World Poverty: An Inquiry into its Cause and Consequences, New York: New York University Press for IFAD.

IFAD. 1999a. India: Country Strategic Opportunities Paper. Report No. 896-IN. February 1999.

IFAD. 1999b. Bangladesh: Country Strategic Opportunities Paper. Report No. 998-BD. December 1999. 
IFAD. 2000. The Kingdom of Nepal: Country Strategic Opportunities Paper. Report No. 1077-NP. May 2000.

IFAD. 2001. Rural Poverty Report 2001: The Challenge of Ending Rural Poverty. Oxford University Press.

IFAD. 2002a. Enabling the Rural Poor to Overcome Their Poverty: Strategic Framework for IFAD 2002-2006. March 2002.

IFAD. 2002b. Regional Strategy Paper: IFAD Strategy for Rural Poverty Reduction in Asia and the Pacific. March 2002.

IFAD. 2002c. Assessment of Rural Poverty-Asia and the Pacific. Rome

IFAD. 2003. Indigenous Peoples and Sustainable Development: Roundtable Discussion Paper for the Twenty-Fifth Anniversary Session of IFAD’s Governing Council. February 2003.

IFAD. 2004. Rural Enterprises and Poverty Reduction. Roundtable Discussion Paper for the Twenty-Seventh Session of IFAD’s Governing Council. February 2004.

Kabeer, N. 1999. Resources, Agency, Achievements: Reflections on the Measurement of Women's Empowerment. Development and Change, 30, 435-464.

Mellor, J. W. 1976. The New Economics of Growth: A Strategy for India and the Developing World. Cornell University Press: Ithaca, NY.

Mellor, J.W. and U. Lele. 1972. Growth Linkages of the New Food Grain Technologies. Indian Journal of Agricultural Economics 19 (1): 35-55.

Mencher, J. 1989. “Women’s Work and Poverty: Women’s Contribution to Household Maintenance in Two Regions of South India.” In D. Dwyer and J. Bruce (eds.). A Home Divided: Women and Income Control in the Third World. Stanford University Press.

Pretty, Jules. 1995. Regenerative Agriculture: Policies and Practice for Sustainability and Self-Reliance. Earthscan Publications Limited: London.

Rahman, R. 1999. Empowerment of the Poor and Women: Role of MFIs in Bangladesh. Paper prepared for Assessment of Rural Poverty in Asia and the Pacific, IFAD, Rome.

Rahman, A. and J. Westley. 2001. The Challenge of Ending Rural Poverty. Development Policy Review, 19 (4): 553-562 
Rosegrant, M. and P. Pingali. 1991. Sustaining Rice Productivity Growth in Asia: A Policy Perspective. IRRI Social Science Division Paper No. 90-01 International Rice Research Institute (IRRI), Los Banos.

Rosegrant, M. and P. Hazell. 2000. Transforming the Rural Asian Economy: The Unfinished Revolution. Oxford University Press, Hong Kong.

SAPPROS. 2001. A Study on Rural Hill Potentials and Service Delivery Systems: Final Draft Report Submitted to IFAD: Rome and Kathmandu.

Scialabba, N., 2000, “Opportunities and constraints of organic agriculture - A socioecological analysis, Summer course of the Socrates Programme, Università Degli Studi Della Tuscia, Viterbo.

Seabright, P. 1997. Is Cooperation Habit Forming? In Dasgupta, P. and Maler, K.G. (eds.) Environment and Emerging Development Issues. Clarendon Press, Oxford.

Sen, A. 1992. Missing Women. British Medical Journal 304 (6827):587-88.

UNDP. 1997. Human Development Report 1997. New York. Oxford University Press.

World Bank. 1992. World Development Report. World Bank: Washington D.C.

World Bank, 1998a. Reducing Poverty in India: Options for More Effective Public Services. Washington, D.C. The World Bank.

World Bank. 1998b. World Development Indicators. 1998. Washington, D.C.

World Bank. World Development Report 2000-2001. Washington D.C.

World Bank. 2004. Global Economic Prospects 2004. Washington D.C. 
Table 1. Regional Comparison of Income Poverty in Developing Countries

\begin{tabular}{|l|r|r|l|r|}
\hline & \multicolumn{2}{|l|}{$\begin{array}{l}\text { People living on less } \\
\text { than US\$1 a day } \\
\text { (million) }\end{array}$} & \multicolumn{2}{l|}{$\begin{array}{l}\text { Share of population } \\
\text { living on less than } \\
\text { US\$1 a day (percent) }\end{array}$} \\
\hline Region & $\mathbf{1 9 9 0}$ & $\mathbf{2 0 0 0}$ & $\mathbf{1 9 9 0}$ & $\mathbf{2 0 0 0}$ \\
\hline East Asia and Pacific & 470 & 261 & 29.4 & 14.5 \\
\hline South Asia & 466 & 432 & 41.5 & 31.9 \\
\hline Europe and Central Asia & 6 & 20 & 1.4 & 4.2 \\
\hline Latin America and Caribbean & 48 & 56 & 11.0 & 10.8 \\
\hline Middle East and North Africa & 5 & 8 & 2.1 & 2.8 \\
\hline Sub-Saharan Africa & 241 & 323 & 47.4 & 49.0 \\
\hline Total & $\mathbf{1 2 3 7}$ & $\mathbf{1 1 0 0}$ & $\mathbf{2 8 . 3}$ & $\mathbf{2 4 . 5}$ \\
\hline
\end{tabular}

Source: World Bank 2004. Global Economic Prospects 2004. 
Table 2. Distribution of poor in rural and urban households in South Asia

\begin{tabular}{|l|l|l|}
\hline Country/year & \multicolumn{2}{|l|}{ Distribution of Poor } \\
\hline & Rural & Urban \\
\hline India, 1994 & 86.2 & 13.8 \\
\hline Pakistan, 1990/91 & 75.0 & 25.0 \\
\hline Bangladesh, 1995/96 & 57.8 & 42.2 \\
\hline Nepal, 1995/96 & 94.0 & 6.0 \\
\hline & & \\
\hline
\end{tabular}

Source: Ahuja et al 1997.

Table 3. Incidence of rural and urban poverty in South Asia

\begin{tabular}{|l|l|l|l|}
\hline Country/year & \multicolumn{3}{l}{ Poverty Headcount Index } \\
\hline & Rural & Urban & Rural-Urban Ratio \\
\hline Bangladesh 1983-84 (b) & 53.8 & 40.9 & 1.32 \\
\hline Bangladesh 1991-92 & 52.9 & 33.6 & 1.57 \\
\hline Bangladesh 1991-92 (a) & 46.0 & 23.3 & 1.97 \\
\hline Bangladesh 1995-96 & 39.8 & 14.3 & 2.78 \\
\hline India 1992 (a) & 43.5 & 33.7 & 1.29 \\
\hline India 1994 & 36.7 & 30.5 & 1.20 \\
\hline India 1957-58 (d) & 55.2 & 47.8 & 1.15 \\
\hline India 1977-78 & 50.6 & 40.5 & 1.25 \\
\hline India 1987-88 & 38.9 & 35.6 & 1.09 \\
\hline India 1990-91 & 36.4 & 32.8 & 1.11 \\
\hline India 1994-95 & 34.2 & 28.4 & 1.20 \\
\hline India 1995-96 & 35.4 & 27.3 & 1.30 \\
\hline India 1997 & 34.2 & 27.9 & 1.23 \\
\hline Nepal 1995-96 (a) & 44.0 & 23.0 & 1.91 \\
\hline Pakistan 1990-91 (a) & 36.9 & 28.0 & 1.32 \\
\hline Pakistan 1984-85 ( & 49.3 & 38.2 & 1.29 \\
\hline Pakistan 1990-91 & 36.9 & 28.0 & 1.32 \\
\hline Sri Lanka 1985-86 (a) & 45.5 & 26.8 & 1.70 \\
\hline Sri Lanka 1990-91 & 38.1 & 28.4 & 1.34 \\
\hline Sri Lanka 1985-86 (b) & 31.7 & 16.4 & 1.93 \\
\hline Sri Lanka 1990-91 & 24.4 & 18.3 & 1.33 \\
\hline
\end{tabular}

Source: IFAD 2001 [Original sources: (a) World Bank 2000 (b) Lipton and Eastwood 1999 (c) de Haan and Lipton 1999 (d) Jha 1999] 
Table 4. Impact of Resource-Conserving Technologies and Practices in Complex and Diverse Agricultural Systems in Asia

\begin{tabular}{|l|l|l|l|l|}
\hline Country/location & Technologies & Yields (t/ha) & $\begin{array}{l}\text { Increase in } \\
\text { yield (\%) }\end{array}$ & Scale \\
\hline $\begin{array}{l}\text { China, Jiangxi } \\
\text { Province }\end{array}$ & $\begin{array}{l}\text { Soil conservation } \\
\text { and watershed } \\
\text { management }\end{array}$ & No data & $152 \%$ & 3,200 families \\
\hline India, Gujarat & $\begin{array}{l}\text { Soil and water } \\
\text { conservation, } \\
\text { biogas }\end{array}$ & No data & $\begin{array}{l}\text { Rice:253\% } \\
\text { Soybean:117\% } \\
\text { Pigeonpea:222\% } \\
\text { Cotton:153\% }\end{array}$ & $\begin{array}{l}\text { Programme in } \\
100 \\
\text { communities }\end{array}$ \\
\hline India, Tamil Nadu & $\begin{array}{l}\text { Contour bunds, } \\
\text { percolation tanks, } \\
\text { gully checks, } \\
\text { agroforestry }\end{array}$ & $\begin{array}{l}\text { Rice: no data } \\
\text { Gram: 0.4 }\end{array}$ & $\begin{array}{l}\text { Same yield, new } \\
\text { second crop } \\
\text { harvested }\end{array}$ & $\begin{array}{l}\text { Programme in } \\
\text { 45 villages }\end{array}$ \\
\hline India, Maharashtra & $\begin{array}{l}\text { Soil and water } \\
\text { conservation }\end{array}$ & $\begin{array}{l}\text { Soybean (dry): } \\
0.7 ; \text { soybean } \\
\text { (irrigated): 2.2 }\end{array}$ & 350\%; 176\% & $\begin{array}{l}\text { One community } \\
\text { of 168 ha }\end{array}$ \\
\hline India, Haryana & $\begin{array}{l}\text { Soil and water } \\
\text { conservation, } \\
\text { social fencing }\end{array}$ & Grass: no data & $400-600 \%$ & 50 communities \\
\hline India, Rajasthan & $\begin{array}{l}\text { Grass strips, field } \\
\text { and contour } \\
\text { bunding }\end{array}$ & $\begin{array}{l}\text { Soybean: 0.33- } \\
0.46 ; \text { Millet: 0.72- } \\
0.93\end{array}$ & $\begin{array}{l}210-292 \% ; 120- \\
154 \%\end{array}$ & No data \\
\hline
\end{tabular}

Source: Pretty 1995 (Table 5.5) 
Table 5. Market Access Constraints: Physical, Structural, Information and Organization

\begin{tabular}{|l|l|l|}
\hline Constraint & Disadvantaged areas & Disadvantaged groups \\
\hline Physical & $\begin{array}{l}\text { Poor roads, high transport } \\
\text { costs, perishable goods, low } \\
\text { value/weight produce. }\end{array}$ & $\begin{array}{l}\text { Those located far from } \\
\text { markets; women with heavy } \\
\text { time burdens; those with } \\
\text { poor access to facilities. }\end{array}$ \\
\hline Structural & $\begin{array}{l}\text { Asymmetry of market } \\
\text { relations: reliance on } \\
\text { monopsonistic traders, agro- } \\
\text { processors or marketing } \\
\text { boards whose market power } \\
\text { allows excess profit shares. }\end{array}$ & $\begin{array}{l}\text { Those with poor access to } \\
\text { land and credit to allow } \\
\text { diversification, } \\
\text { commercialization and/or } \\
\text { marketing of goods in wider } \\
\text { markets; those constrained } \\
\text { by traditional or cultural } \\
\text { norms. }\end{array}$ \\
\hline $\begin{array}{l}\text { Skills, information and } \\
\text { organization }\end{array}$ & $\begin{array}{l}\text { Lack of understanding of } \\
\text { how markets operate, lack of } \\
\text { information, lack of relevant } \\
\text { skills. }\end{array}$ & $\begin{array}{l}\text { Most of rural poor; those } \\
\text { who lack education and } \\
\text { collective organization. }\end{array}$ \\
\hline
\end{tabular}

Source: IFAD 2001 